\title{
DINAMIKA PERKEMBANGAN SPIRITUALITAS DAN RELEVANSINYA TERHADAP PENDIDIKAN ISLAM
}

\author{
Nove Kurniati Sari \\ Universitas Islam Negeri Sunan Kalijaga Yogyakarta \\ Email:noveophe@gmail.com
}

\begin{abstract}
This article is expected to provide an understanding especially for educators about the spiritual development of children which has an impact on the ease of carrying out Islamic education. It is also expected to facilitate educators to form and develop spiritual attitudes early on and be carried out in accordance with the cognitive and emotional characteristics of the child itself. This article is a literature study by examining relevant books and print and online journals, both national journals and other journals that can be a source of discussion of issues in this research topic. The results of the discussion of this article are what are the stages of the child's spiritual development and how these stages affect children's acceptance in the process of Islamic education. In addition, it can be seen that each stage of spiritual development is in tune with the physical and psychological development, which is also influenced by the child's interaction with the environment.
\end{abstract}

Keywords: Development, Spiritual, Education, Children

\begin{abstract}
ABSTRAK
Artikel ini diharapkan dapat memberi pemahaman terutama kepada pendidik tentang perkembangan spiritual anak yang berdampak pada kemudahan dalam melaksanakan pendidikan Islam. Selain itu diharapkan dapat memudahkan pendidik untuk membentuk dan mengembangkan sikap spiritual sedari dini dan dilakukan sesuai dengan karakteristik kognitif dan emosi anak itu sendiri. Artikel ini adalah penelitian kepustakaan dengan mengkaji buku-buku relevan serta jurnal cetak maupun online, baik jurnal nasional dan jurnal lain yang dapat menjadi sumber pembahasan permasalahan dalam topik penelitian ini. Hasil pembahasan artikel ini adalah apa saja tahapan perkembangan rasa spiritual anak dan bagaimana keberpengaruhan tahapan tersebut terhadap penerimaan anak dalam proses pendidikan Islamnya. Selain itu dapat diketahui bahwa setiap tahap perkembangan rasa spiritual seiringan dengan perkembangan fisik dan psikisnya, yang dipengaruhi juga oleh interaksi anak dengan lingkungan.
\end{abstract}

Kata Kunci: Perkembangan, Spiritual, Pendidikan, Anak 


\section{PENDAHULUAN}

Manusia lahir ke dunia ini tanpa membawa pengetahuan apapun. Namun manusia telah diberi kemampuan bawaan yang bisa dikembangkan. Kemampuan ini tidak lain adalah sebuah potensi yang perlu dikembangkan dan dibimbing serta dipelihara terutama sejak seorang individu masih berusia muda (anak-anak). Anakanak masih memiliki potensi perkembangan jiwa yang baik, dimana ia masi dalam tahap belajar dan menyerap pengetahuan religius dari luar dirinya yaitu lingkungan terdekatnya ${ }^{1}$. Fisik dan jasmani yang ada pada anak memiliki peluang untuk berkembang secara sempurna jika dipelihara dan dilatih dengan benar. Begitu juga dengan perkembangan akal dan mentalnya pun dapat berfungsi jika proses bimbingan diarahkan kepada proses eksplorasi secara menyeluruh. Eksploarasi secara menyeluruh ini dilakukan secara bertahap, menyesuaikan tahap perkembangan anak, serta perkembangan agama pada diri anak.

Anak-anak adalah manusia yang berumur antara 0-12 tahun. Sesuai dengan yang diungkapkan oleh Elizabeth B. Hurlock, yaitu masa anak-anak terdiri dari tiga tahapan: 1) $0-2$ tahun (masa vital); 2) $2-6$ tahun (masa kanak- kanak); 3) 6-12 tahun (masa sekolah). Anak-anak jelas kedudukannya, yaitu yang belum dapat hidup sendiri, belum matang dari segala segi, tubuh masih kecil, organ-organ belum dapat menjalankan fungsinya secara sempurna, kecerdasan, emosi dan hubungan sosial belum selesai pertumbuhannya. Hidupnya masih bergantung pada orang dewasa, belum dapat diberi tanggung jawab atas segala hal. Dan mereka menerima kedudukan seperti itu.

Tahap perkembangan kehidupan manusia terbagi ke dalam lima bagian, yaitu: 1) umur 0-3 tahun, periode vital (masa menyusui); 2) umur 3-6 tahun, periode estetis (masa bermain); 3) umur 6-12 tahun, periode intelektual (masa sekolah); 4) umur 1221 tahun (masa pemuda); 5) umur 21 tahun ke atas, (periode dewasa atau masa kematangan $)^{2}$.

Anak memahami konsep ketuhanan melalui kata-kata orang yang ada di sekitarnya, yang pada awalnya tidak begitu ia pahami. Anak belum mempunyai pengetahuan yang akan membawanya ke pemahaman apa itu Tuhan, baik pengalaman fisik maupun psikis. Namun, dengan pengamatan dan pengetahuan dari

\footnotetext{
${ }^{1}$ Jalaluddin, Psikologi Agama, (Jakarta: Raja Grafindo Persada, 2005), hlm. 70.

${ }^{2}$ Kohnstamm, dalam Mustaqim, Psikologi Pendidikan, (Semarang : Pustaka Pelajar, 2004),
} hlm. 16. 
orang disekitarnya, disertai dengan ditanamkannya perasaan tertentu maka mulailah perhatiannya terhadap konsep ketuhanan itu tumbuh ${ }^{3}$. Jadi, dengan kata lain jiwa agama adalah perilaku-perilaku yang berhubungan dengan kehidupan beragama seorang individu dan pengaruh keyakinan tersebut kepada dirinya serta keadaan hidupnya secara keseluruhan.

Pada anak-anak, ide keagamaan dipengaruhi oleh perkembangan berbagai aspek kejiwaannnya serta perkembangan berpikir. Namun tidak hanya itu, sebagaimana dipaparkan oleh Jalaluddin, bahwa " Konsep religius pada diri anak dipengaruhi oleh faktor dari lingungan mereka atau hampir sepenuhnya authoritarius"4. Dengan kata lain, anak-anak melihat dan mempelajari konsep-konsep dan nilai-nilai religius dari lingkungan terdekat mereka. Apa yang dikerjakan serta diajarkan orang dewasa dan orang tua mereka tentang sesuatu yang berhubungan dengan agama menjadi sumber pengetahuan utama tentang aspek religius. Ini juga berarti bahwa orang tua mempunyai pengaruh terhadap anak sesuai dengan prinsip eksplorasi dan imitasi (meniru) yang anak miliki, dengan demikian pemahaman tentang agama anak terbentuk dari kebiasaan yang anak dari para orang tua maupun guru mereka. Bagi mereka sangat mudah untuk menerima ajaran dari orang dewasa, walaupun belum mereka sadari sepenuhnya manfaat ajaran tersebut.

Orang tua perlu memahami tahap perkembangan religius anak, sehingga dapat melakukan bimbingan dan pembinaan yang dapat memaksimalkan potensi anak dengan baik. Hal ini sejalan dengan pernyataan Jalaluddin bahwa peran ibu bapak dalam membentuk jiwa religius pada anak adalah sebuah peran yang strategis. Jika dikaitkan dengan akidah, proses religius pada anak harus dibimbing dan diarahkan terutama oleh orang tuanya sehingga tidak akan salah $\operatorname{arah}^{5}$

\section{DEFINISI PERKEMBANGAN RASA RELIGIUS}

Perspektif perkembangan rasa, tidak terfokus pada aspek ritualitas, normatifitas atau kebenaran agama, tetapi sebatas pada kepercayaan serta pengaruhnya terhadap proses mental seorang individu. Pengaruh agama terhadap seorang individu, dapat diamati dari gejala-gejala dalam perilaku, tindakan, luapan perasaan, dan emosi.

\footnotetext{
${ }^{3}$ Zakiah Darajat, Ilmu Jiwa Agama, (Jakarta: Bulan Bintang, 1987), hlm. 31.

${ }^{4}$ Jalaluddin, Psikiologi Agama, (Jakarta: PT Raja Grafindo Persada, 2005), hlm.70)

${ }^{5}$ Ibid, hlm.66.
} 


\section{TAHAP PERKEMBANGAN RASA RELIGIUS}

Tahap-tahap perkembangan rasa agama menurut Anshari ${ }^{6}$ adalah Pertama, tahap pembentukan pada usia anak-anak yang merupakan tahap pengenalan dan pengkristalan nilai-nilai agama dasar, ditunjukan dengan adanya tugas-tugas religius. Crapps $^{7}$ mengatakan bahwa dalam tahap ini, anak belajar agama dari sisi emosional dan religius bersumber dari pengalaman dan interaksi antar pribadi dengan keluarga. Pengetahuan yang didapat anak pada masa ini lebih berpengaruh dibanding pendidikan religius dikemudian hari. Menurut Jalaluddin ${ }^{8}$ ada beberapa sifat-sifat agama pada masa kanak-kanak, yaitu bersifat unreflective (tidak mendalam), anthromorphis (konsep ketuhanan yang menggambarkan aspek-aspek kemanusiaan), imitative (diperoleh melalui meniru), verbalis-ritualis (belajar mengucapkan kalimatkalimat religius dan kebiasaan), rasa heran (keheranan secara lahiriah saja). Kedua, tahap pengembangan adalah tahap pemaknaan dan mulai berfungsinya nilai-nilai dasar religius. Tahap ini ada pada masa remaja dimanaproses perkembangannya sejalan dengan perkembangan jasmani dan rohaninya. Menurut Ramayulis ${ }^{9}$ tahap perkembangan masa remaja menduduki tahap progresif yang mencakup masa: Juvenilitas (adolescantium), pubertas, dan nubilitas. Menurut W. Starbuck ${ }^{10}$ perkembangan pada masa remaja ditandai oleh beberapa faktor perkembangan jasmani dan rohaninya, perkembangan itu antara lain adalah:

1. Pertumbuhan Pikiran dan Mental

Dasar religius yang diterima seseorang dari masa kanak-kanaknya sudah dipahami secara berbeda. Sifat kritis mulai dikembangkan tidak hanya pada persoalan agama namun juga pada aspek ekonomi, sosial-budaya dan isu-isu kehidupan lainnya. Pada masa remaja seorang anak mulai mempertanyakan nilainilai kongkrit yang mereka terima saat kecil dan mengembangkannya ke arah nilainilai abstrak. Hal ini sesuai dengan teori perkembangan kognitif yang dikemukakan

6 Endang Saifuddin Anshari, Wawasan Islam: Paradigma dan Sistem Islam, (Jakarta: Rajawali, 1991), hlm. 67-97.

${ }^{7}$ Robert W. Crapps, Dialog Psikologi dan Agama, (Yogyakarta: Kasinus, 1993), hlm. 14.

8 Jalaluddin, Psikologi Agama: Sebuah Pengantar, (Jakarta: PT. Raja Grafindo Persada, 2003), hlm. 70-73.

${ }^{9}$ Ramayulis, Ilmu Jiwa Agama, (Jakarta: Kalam Mulia, 2007), hlm. 58.

10 Jalaluddin, Psikologi Agama: Sebuah Pengantar, (Jakarta: PT. Raja Grafindo Persada, 2003), hlm. 74-77. 
oleh Piaget ${ }^{11}$ dimana tahapan ini termasuk ke dalam fase operasi kongkrit dan fase operasional formal, dimana anak mulai berfikir menggunakan logika, dimana bentuk aktivitas dapat ditemukan dengan peraturan yang berlaku. Selain itu, anak telah dapat mengembangkan pola-pola berfikir formal, logis, rasional, bahkan abstrak, mampu menangkap arti simbolis, kiasan, dan menyimpulkan suatu berita, dan sebagainya.

\section{Perkembangan Perasaan}

Emosi dan perasaan sering mendominasi masa remaja yang masih mencari jati diri. Kehidupan religius akan mendorong remaja ke arah yang religius pula. Sebaliknya remaja yang kurang mendapatkan pemahaman religius akan cenderung dikuasai kecenderungan eksplorasi seksualnya yang sedang berkembang. Hal ini dibuktikan dengan penelitian Dr. Kinsey ${ }^{12}$ yang mengungkap bahwa hampir $90 \%$ remaja di Amerika banyak yang terjerumus pada homoseksual dan kebiasaan onani.

3. Perkembangan Sosial

Masa remaja juga ditandai dengan munculnya sikap sosial, dimana hal ini terlihat pada timbulnya konflik antara pertimbangan moral dan material. Seperti dilema saat mereka mengetahui bahwa merokok itu tidak baik, namun akhirnya tergoda untuk merokok karena dipengaruhi teman-temannya.

4. Perkembangan Moral

Perkembangan moral pada anak bertitik tolak dari rasa berdosa dan usaha untuk diterima di lingkungannya. Tipe moral yang terlihat pada anak juga mencakupi:

a. Self-directive, ketaatan berdasarkan pertimbangan pribadi.

b. Adaptive, patuh norma lingkungan tanpa adanya kritik.

c. Submissive, patuh namun ragu pada ajaran agama dan moral.

d. Unadjusted, mempertanyakan kebenaran ajaran agama dan moral.

e. Deviant, menolak dasar religius serta tatanan moral masyarakat.

5. Sikap dan Minat

Sikap dan minat anak terhadap masalah religiusnya boleh dikatakan sangat kecil dan hal ini tergantung dari kebiasaan masa kecil serta lingkungan agama yang mempengaruhi mereka (besar kecil minatnya).

${ }^{11}$ Otib Satibi Hidayat, Metode Pengembangan Moral Dan Nilai-Nilai Agama, (Jakarta: Universitas Terbuka, 2008), hlm. 25.

${ }_{12}$ Jalaluddin, Psikologi Agama: Sebuah Pengantar, (Jakarta: PT. Raja Grafindo Persada, 2003), hlm. 75. 
6. Ibadah

Bagi sebagian anak ibadah merupakan hal sepele. Ini bisa dilihat dari ketaatan mereka dalam menjalankan ibadah sehari-hari. Pada masa anak dikenal sebagai usia rawan akan agama yang mereka terima. Anak akan mengalami keraguan dan kebimbangan termasuk dalam aspek religius mereka. Untuk mengatasi kebimbangan itu, maka seyogyanya mereka memerlukan bimbingan dan pengarahan. Para anak memerlukan tokoh pelindung yang mampu diajak berdialog dan berbagi rasa ${ }^{13}$. Dari hasil analisis penelitiannya W. Starbuck ${ }^{14}$ menemukan penyebab timbulnya keraguan dan kebimbangan dalam perkembangan rasa religius itu antara lain:

a. Kepribadian, yang menyangkut salah tafsir dan jenis kelamin

1) Bagi seorang yang memiliki kepribadian introvert, maka kegagalan dalam mendapatkan apa yang ia inginkan akan Tuhan yang tidak menyayangi dan tidak mengabulkan keinginannya.

2) Anak perempuan secara umum lebih cepat matang dalam perkembangannya dan lebih cepat menyerap konsep agama dari pada anak lelaki. Tetapi sebaliknya dalam kualitas dan kuantitas keraguan anak perempuan lebih kecil jumlahnya. Disamping itu keraguan wanita lebih bersifat alamiah sedangkan pria bersifat intelek.

b. Kesalahan organisasi religius dan pemuka agama

Pertentang-pertentangan dalam organisasi keagamaan dan tindak-tanduk pemuka agama yang jauh menyimpang akan menimbulkan keraguan pada anak.

c. Pernyataan kebutuhan manusia

Manusia memiliki rasa ingin tahu. Berdasarkan faktor bawaan ini manusia terdorong untuk mempelajari ajaran agama dan kalau ada perbedaanperbedaan yang kurang sejalan dengan apa yang telah dimilikinya akan timbul keraguan.

d. Kebiasaan

Seseorang yang terbiasa dengan tradisi religius yang dianutnya akan ragu menerima kebenaran ajaran yang baru diterima atau dilihatnya. Namun, keraguan ini ada yang menimbulkan rasa penasaran dan kemudian mereka

${ }^{13}$ Jalaluddin, Psikologi Agama: Sebuah Pengantar, (Jakarta: PT. Raja Grafindo Persada, 2003), hlm. 81.

${ }^{14}$ Ramayulis, Ilmu Jiwa Agama, (Jakarta: Kalam Mulia, 2007), hlm. 61-63. 
berusaha mencari kebenaran dengan membandingkan kedua ajaran tersebut. Maka tidak tertutup kemungkinan mereka pindah agama.

e. Pendidikan

Dasar pengetahuan yang dimiliki seseorang sesuai dengan tingkat pendidikan yang ia miliki akan membawa pengaruh sikap terhadap ajaran agamanya. Hal ini berdampak pada kemampuan mereka menafsirkan ajaran agamanya.

f. Percampuran agama dan tradisi

Sejalan dengan perkembangn masyarakat kadang secara tidak sadar tindak keagamaan yang dijalankan oleh masyarakat berupa percampuran praktek religius dan tradisi. Penyatuan unsur ini merupakan sesuatu yang memunculkan pertanyaan pada diri anak.

Ketiga, tahap dinamik adalah tahap pematangan dan mulai berpengaruhnya nilai-nilai agama pada seluruh aspek kehidupan (agama sebagai "Way of Life"), tahap ini berada pada usia dewasa. Menurut Sujanto ${ }^{15}$ saat mengakhiri masa remasa menuju masa dewasa pada umumnya orang akan berusaha menemukan jati dirinya, menentukan jalan hidupnya serta menyerap norma disekitarnya. Maka pandangan hidup seseorang pada masa ini telah mencapai kestabilan baik aspek agama yang dianutnya maupun nilai-nilai yang dianggap benar dan diperlukan dalam hidupnya. Kestabilan yang dimaksud disini bersifat dinamis, dimana dapat berubah sesuai kondisi dan pengetahuan mereka dapatkan. Maka ada kemungkinan terjadinya religious konversion (pindah agama) karena seseorang mengalami kebimbangan, keraguan atau konflik. Masalah pendidikan yang melahirkan pemikiran baru atau anggapan bahwa ajaran agama yang tidak lagi relevan dengan tuntutan masa dan kehidupan. Zakiah Darajat ${ }^{16}$ mengemukakan faktor-faktor terjadinya konversi adalah karena pertentangan batin (konflik jiwa) dan ketegangan perasaan, pengaruh hubungan dengan tradisi agama, ajakan dan sugesti, faktor-faktor emosi, dan kemauan.

15 Endang Saifuddin Anshari, Wawasan Islam: Paradigma dan Sistem Islam, (Jakarta: Rajawali, 1991), hlm. 89-90, 94

${ }^{16}$ Ibid., hlm 97. 
Keempat, tahap pemeliharaan adalah tahap dimana agama menguasai tujuan dan aktifitas kehidupan (wordly ascetisme). Berada pada usia lanjut, menurut Jalaluddin ${ }^{17}$ ciri keberagamaan lanjut usia adalah:

1. Meningkatnya kecenderungan untuk menerima pendapat keagamaan.

2. Pengakuan tentang kehidupan akhirat secara dan timbulnya rasa takut kepada kematian.

3. Sikap keagamaan cenderung mengarah kepada kebutuhan saling cinta antar sesama manusia.

\section{Dinamika Perkembangan Aspek Religius Dalam Pendidikan Islam}

Proses penyesuaian sikap religius dengan tingkap perkembangan kognitif dan tahap kesadaran agama seorang anak sangat diperlukan. Berikut ini adalah metodemetode yang dapat diterapkan orang tua maupun pendidik yang disesuaikan dengan tahap perkembangan pemahaman anak, untuk termujudnya sikap religius yang sempurna:

1. Contoh dari orang sekitarnya. Karena anak-anak cenderung imitatif terhadap apa yang dilihat dan dialaminya kemudian diterapkan dalam segala praktek kehidupannya, maka contoh yang baik dari orang terdekatnya sangat diperlukan agar anak mendapat figur yang tepat dan bisa ia tiru. Begitu pula jika anak melihat contoh yang kurang baik dari orang sekitarnya, maka sikap kurang baik pula dapat berkembang dalam diri anak.

2. Sugesti dan koreksi. Anak diberi sugesti untuk mengarahkannya melakukan praktek-praktek religius seperti shalat, mengaji, sedekah, dan lain-lain. Kemudian jika anak melakukan kekeliruan, harus dilakukan follow-up dalam bentuk koreksi yang kontinu dari orang-orang terdekat tentang bagaimana praktek yang benar.

3. Dorongan sosial. Anak juga dapat mengembangkan aspek religius dari kelompok sosialnya. Sehingga anak perlu diberikan keleluasaan untuk berinteraksi dengan teman sebayanya untuk mengembangkan sikap penghargaan, toleransi, dan sikap religiusnya. Karena aspek religius tidak terbatas pada kepentingan perseorangan saja, namun juga untuk diterapkan dalam kehidupan bermasyarakat. Dengan memberikan anak untuk bergaul dengan teman-temannya, diharapkan anak bisa mengembangkan kepekaan sosial dan lebih termotivasi dalam beragama karena teman-temannya tersebut.

17 Jalaluddin, Psikologi Agama: Sebuah Pengantar, (Jakarta: PT. Raja Grafindo Persada, 2003), hlm. 105-106. 
Orang tua adalah sosok pertama dimana anak menerima pengetahuan dan belajar hal-hal dasar untuk kehidupannya. Sehingga orang tua atau keluarga adalah tempat yang tepat untuk memulai proses pembentukan sikap religius dan keagamaan seorang anak. Pada masa awal kehidupan anak, hampir sepanjang hari anak hanya berinteraksi dengan orang tua, sehingga ia hanya meniru dan mempelajari dari apa yang orang tuanya berikan. Sehingga disinilah ornag tua dapat menanamkan nilai religius secara mendalam pada.

Anak-anak tentulah berbeda dengan orang dewasa. Anak-anak masih belum mengembangkan pemahaman terhadap hal-hal abstrak. Mereka masih berorientasi terhadap hal-hal yang bisa terlihat dan dirasakan langsung oleh mereka. Oleh karena itu perlunya penyesuaian bahasa dan cara penyampaian yang benar sehingga apa yang disampaikan dapat dipahami seorang anak.

Menurut Zakiah Darajat pembentukan sikap keberagamaan pada anak harus dilakukan sejak dini, dimulai dari lingkungan terdekat anak seperti keluarga, sekolah dan masyarakat ${ }^{18}$. Semakin besar intensitas pengalaman anak, maka perkembangan sikap religius pada anak dapat diarahkan secara maksimal. Zakiah Darajat juga menjelaskan bahwa pembinaan dan pembiasaan yang kontinu adalah cara yang dapat dilakukan untuk memberikan pengalaman religius kepada anak. Proses pendidikan formal dan informal dapat mewujudkan pribadi anak yang baik, kuat, serta sikap keberagamaan yang baik dan akhlak terpuji ${ }^{19}$. Pengalaman yang diperoleh anak baik melalui penglihatan, pendengaran maupun perlakuan yang diterima dari proses pendidikan juga turut berperan dalam membentuk dan mengembangkan aspek religius anak.

Perkembangan sikap religius anak sangat dipengaruhi oleh interksi dalam kehidupan keluarganya. Jika seorang anak diberi kehidupan yang harmonis dan ruang untuk bereksplorasi, tentulah anak dapat berkembang ke arah yang baik. Sebaliknya, jika keluarganya kurang harmonis, dapat berdampak pada pribadi anak sukar untuk dibentuk. Hal ini disebabkan karena perkembangan anak terganggu oleh suasana ketidaharmonisan orang tuanya yang ia lihat terus-menerus ${ }^{20}$. Selain itu, pengalamanpengalaman religius yang sudah dimiliki oleh anak yang diperoleh di rumah seperti tata krama, sopan satun, adab bicara, shalat, mengaji, dan lain-lain, akan

\footnotetext{
${ }^{18}$ Zakiyah Daradjat, Ilmu Jiwa Agama ... , hlm 55.

${ }^{19}$ Ibid., hlm. 56.

${ }^{20}$ Ibid.
} 
mempengaruhi sikap anak di sekolah. Tentulah pengalaman religus tersebut perlu dilakukan dengan memberikan rasa nyaman dan aman kepada anak. Apabila latihanlatihan tersebut diberikan dengan cara yang salah dan tidak sesuai dengan pemahaman anak, maka bisa saja berdampak pada masa dewasa si anak yang kurang religius $^{21}$.

Pendidik mempunyai tugas tidak hanya sekedar mengajarkan ilmu eksak kepada anak, tapi juga membina karakter dan memperbaiki sikap anak apabila terlanjur mencontoh hal-hal yang tidak baik. Pendidik juga diharapkan membantu serta memberikan dukungan terhadap nilai-nilai religius dan kebaikan yang sudah didapat anak dari keluarganya. Oleh karena itu, dengan kata lain pendidik atau guru adalah agen penyempurna sikap religius anak, baik segi pengembangan maupun penambahan nilai kebaikan selama proses transfer pengetahuan anak dalam pendidikan. Tidak hanya sekedar transfer pengetahuan, namun juga transfer nilai dan norma religius serta sosial perlu dilakukan pendidik dengan cara yang baik dan menyeluruh untuk membantu perkembangan anak dan menjadikannya individu yang baik.

\section{PEMBINAAN ASPEK RELIGIUS PADA USIA ANAK}

Pembinaan agama pada pribadi anak sangat memerelukan pembiasaan dan latihan-latihan yang cocok dan yang sesuai dengan perkembangan jiwanya. Karena pembiasaan dan latihan-latihan tersebut akan membentuk sikap tertentu pada anak. Sikap-sikap tersebut akan perlahan menjadi kebiasaan si anak yang akan membentuk karakter dan pembawaan dan menjadi dari pribadinya. Namun untuk membina sifat terpuji anak harus dilakukan dengan membiasakannya pada perilaku baik yang diharapkan nanti dia akan menerapkan sifat-sifat itu terus-menerus. Demikian pula dengan pendidikan agama, anak harusnya dilatih dan dibiasakan dengan konsep agama baik yang normatif maupun aplikatif. Sehingga saat bertambahnya umur anak, ia dapat mengembangkan pengetahuan tersebut dan menyerap pengertian tentang agama itu sesuai dengan perkembangan yang dijelaskannya. Pembentukan sikap, pembinaan moral dan pribadi pada umumnya, terjadi melalui pengalaman sejak kecil. Pendidik atau pembina yang pertama adalah orang tua, kemudian guru.

Pemahaman nilai kagamaan pertama kali diberikan kedua orang tuanya, kemudian disempurnakan guru di sekolah maupun di tempat pendidikan non-formal

\footnotetext{
${ }^{21}$ Ibid., hlm. 41.
} 
seperti pengajian di masjid, TPQ, dan Madrasah. Latihan-latihan yang menyangkut ibadah seperti shalat, baca Quran, tata krama, dan lain sebagainya, semua itu harus dibiasakan sejak kecil, sehingga lama-kelamaan akan tumbuh rasa senang terhadap aktifitas tersebut tanpa ada rasa terbebani. Latihan yang baik haruslah diiringi dengan contoh atau teladan yang baik dari orang sekitarnya. Hal ini untuk membentuk pondasi pemahaman anak yang pada tahap berikutnya baru diberikan pengertian tentang norma-norma kereligiusan untuk dapat dipatuhi secara baik.

a. Proses Pembinaan Agama

Nilai akhlakul karimah adalah perilaku dasar yang harus dimiliki seorang anak sebagai tolak ukur keberhasilan dalam pelaksanaan pembinaan agama. Hal ini tentunya membutuhkan upaya-upaya strategis yang harus dilakukan agar pembinaan agama senantiasa dapat selalu menjadi pondasi dalam kehidupan mereka. Adapun langkah-langkah yang dapat ditempuh adalah sebagai berikut:

1) pembinaan agama harus integritas antara ilmu-ilmu aqliah dan ilmu-ilmu naqliah sekarang tidak menciptakan jurang pemisah antara ilmu agama dan ilmu umum;

2) pembinaan agama ditanamkan agar terapainya perilaku toleransi dalam kehidupan tanpa melepaskan prinsip yang diyakininya;

3) pembinaan agama perlu dikonstruksi secara terencana, sistematis dan mendasar untuk menyiapkan generasi muda Islam yang berkualitas.

b. Metode yang digunakan dalam Pembinaan Agama untuk Anak meliputi :

1) Metode Ceramah adalah suatu metode yang cara penyampaian materi-materi dengan jalan menerangkan dan menuturkan secara lisan. Penggunaan metode ini dapat dilakukan dalam penyampaian materi seputar akidah, syariah serta akhlak pada anak-anak.

2) Metode Diskusi atau bisa disebut metode musyawarah adalah suatu metode dalam mengajarkan atau menyampaikan materi dengan merangsang peserta didik untuk berpikir dan mengeluarkan gagasan atau pendapatnya lalu menyumbangkan ide tersebut ke dalam suatu masalah yang terkandung kemungkinan-kemungkinan jawabannya. Dalam pembinaan agama, metode diskusi ini banyak dipergunakan dalam bidang syari'ah dan akhlak.

3) Metode Tanya Jawab adalah penyampaian materi dengan cara mengajukan pertanyaan dan memberikan jawaban pada pertanyaan tersebut. Metode ini dimaksudkan guna mengenalkan fakta-fakta tertentu yang sudah diajarkan dan 
untuk menstimulasi perhatian seseorang dengan berbagai cara. Metode tanya jawab juga banyak dipergunakan dalam pembinaan agama meliputi aqidah syariah dan akhlak. Bahkan ketiga-ketiga itu ajaran Islam tersebut disampaikan oleh Malaikat Jibril kepada nabi Muhammad SAW melalui tanya jawab.

\section{KESIMPULAN}

Aspek religius merupakan sesuatu yang didapat dari proses pendidikan yang diterima individu sepanjang hidupnya dan bukan bawaan. Aspek Religius merupakan suatu keadaan internal individu yang menyebabkan munculnya respon individu untuk bersikap berdasarkan pertimbangan ajaran agama. Rasa religius dibentuk berdasar pengalaman langsung yang terjadi atas interaksi individu dengan lingkungan sosial disekitarnya, misalnya interaksi individu dengan orang tua, teman sebaya, guru, dan masyarakat. Lingkungan keluarga, sekolah dan masyarakat memiliki peran paling besar dalam membentuk aspek religius seseorang anak karena intensitas interaksi dalam kehidupan anak yang lebih banyak pada area-area tersebut.

Karakteristik dan perkembangan sikap keberagamaan individu berbeda-beda, sesuai dengan tahap-tahap perkembangan. Sikap keberagamaan yang dimiliki oleh individu terbentuk melalui tiga komponen, yaitu komponen kognitif, afektif dan psikomotor. Oleh karena itu pembentukan dan pengembangan sisi religius individu harus menyesuaikan dengan karakteristik dan tahap-tahap perkembanganya. Hal ini dapat dilakukan dengan cara, yaitu: Pertama, penyerapan nilai-nilai keislaman dalam keseharian baik secara keteladan, dorongan, maupun sugesti. Kedua, membentuk atmosfer religiusitas baik oleh lingkungan keluarga, sekolah maupun di masyarakat.

\section{DAFTAR PUSTAKA}

Ahmadi, Abu, Psikologi Umum. Jakarta : Rineka Cipta, 2003. , Psikologi Sosial, Jakarta: Renika Cipta, 1991

Ahyadi, Abdul Azis, Psikologi Agama: Kepribadian Muslim Pancasila, Jakarta: Sinar Baru Algensindo, 1999

Ancok, Djamaluddin dan Fuat Anshori Suroso, Psikologi Islami: Solusi Islam atas Problema-Problema Psikologi,cet II. Yogyakarta:pustaka Pelajar, 1995.

Azwar, Saifuddin, Sikap Manusia: Teori dan Pengukurannya, Yogyakarta: Pustaka Pelajar, 1995 
Ali, Muhammad, Perkembangan Peserta Didik, Bandung: PT. Remaja Rosdakarya, 2008

Crapps, Robert W., Dialog Psikologi dan Agama, Yogyakarta: Kasinus, 1994

Darajat, Zakiah, Ilmu Jiwa Agama. Jakarta: Bulan Bintang, 1979.

Dingagunasa, Singgih, Pengantar Ilmu Psikologi. Jakarta: Mutiara Sumber Widya, 1996.

Hidayat, Otib Satibi, Metode Pengembangan Moral Dan Nilai-Nilai Agama, Jakarta: Universitas Terbuka, 2008.

Hidayat, Komaruddin, et.al., Perkembangan Psikologi Agama dan Pendidikan Islam Di Indonesia. Ciputat : Logos Wacana Ilmu, 1999.

Jalaludin, Psikologi Agama, Jakarta: Rajawali Press, 2005 Psikologi Agama: Sebuah Pengantar, Jakarta: PT. Raja Grafindo Persada, 2003

Mujib, Abdul dan Jusuf Mudzakir, Nuansa-nuansa Psikologi Islam. Jakarta: Raja Grafindo Persada, 2002.

Purwanto, Ngalim, Psikologi Pendidikan, Bandung: PT Remaja Rosdakarya, 2004

Ramayulis, Ilmu Jiwa Agama. Jakarta: Kalam Mulia, 2007 , Pengantar Psikologi Agama. Jakarta : Kalam Mulia, 1996.

Santrock, Perkembangan Masa Hidup Jilid I, Jakarta: Erlangga, 2004

Tafsir, Ahmad, Metodologi Pengajaran Agama Islam, Bandung: PT. Remaja Rosdakarya,2005.

Wirawan, Surlito, Pengantar Ilmu Psikologi, cet II. Jakarta : Bulan Bintang, 1982 